\title{
Electrochemical Characterization of Catechol-Dimethylamine Adduct at Different pH Values
}

\author{
K. Riaz Ahamed ${ }^{a}$, B. Arifa Farzana ${ }^{a, *}$, S. Justin Diraviam ${ }^{a}$, \\ R. Dorothy ${ }^{b}$, Susai Rajendran ${ }^{b, c}$ and Abdulhameed Al-Hashem ${ }^{d}$ \\ ${ }^{a} P G$ and Research Department of Chemistry, Jamal Mohamed College (Autonomous), \\ Tiruchirappalli, India \\ ${ }^{b}$ AMET University, 135, East Coast Road, Kanathur-603 112, Chennai, India \\ ${ }^{c}$ Department of Chemistry, St. Antony's College of Arts and Sciences for Women, \\ Dindigul-624 005, Tamil Nadu, India \\ ${ }^{d}$ Petroleum Research Centre, Kuwait Institute for Scientific Research, Kuwait
}

Received June 27, 2017; accepted March 12, 2018

\begin{abstract}
The efficiency of Commelina benghalensis leaves extract as a mild steel corrosion inhibitor in hydrochloric acid $(\mathrm{HCl})$ and sulphuric acid $\left(\mathrm{H}_{2} \mathrm{SO}_{4}\right)$ has been evaluated. The corrosion rates were determined using the gravimetric (weight loss) and electrochemical techniques. The results obtained in the absence and presence of Commelina benghalensis extracts were used to calculate the inhibition efficiency (\%), and to propose the inhibition mechanism and adsorption type. The obtained results showed that the inhibition efficiency increased with the increase in concentration of Commelina benghalensis extract. The phenomenon of chemical adsorption was proposed, and the inhibitor adsorption was found to obey Langmuir, Temkin and kinetic thermodynamic models. The polarization study reveals that, in the inhibitor presence, the corrosion current value decreases, indicating the formation of a protective film on the metal surface, which prevents the electron release from it.
\end{abstract}

Keywords: Commelina benghalensis leaves extract, corrosion inhibition, weight loss, polarization, impedance study, adsorption isotherm and green inhibitors.

\section{Introduction}

Corrosion is a ubiquitous problem that continues to be of great relevance in a wide range of industrial applications and products. The use of corrosion inhibitors is the most economical and practical method in reducing corrosive attack on metals. Nevertheless, the popularity and use of synthetic compounds as corrosion inhibitors are diminishing, due to the strict environmental regulations, and to the toxic effects of synthetic compounds on human and animal life. In

\footnotetext{
*Corresponding author. E-mail address: farzana.arifa@yahoo.com
} 
order to find out non-toxic, cheap and effective green corrosion inhibitors from renewable sources, many natural products have been used by researchers.

Chraibi et al. have used $M$. piperita and $M$. pulegium essential oils for the corrosion control of mild steel in a 1.0 M hydrochloric acid solution [1]. These substances also have antibacterial activity. Evaluation of Alpinia galanga and its active principle, 1'-acetochavicol acetate, as an eco-friendly corrosion inhibitor on mild steel in acidic media, has been done by Ajeigbe et al. [2]. The anticorrosive activity of Schreabera swietenioids leaves as a green inhibitor for mild steel in an acidic solution has been reported by Sivakumar and Srikanth [3]. The corrosion inhibition of carbon steel in a $1 \mathrm{M} \mathrm{H}_{2} \mathrm{SO}_{4}$ solution by Thapsia villosa extracts was investigated by Kalla et al. [4]. The use of Piper longum extract as a green corrosion inhibitor for aluminium in a $\mathrm{NaOH}$ solution has been studied by Singh et al. [5].

Junior et al. have evaluated the antioxidant activity and corrosion inhibition by Brazilian plant extracts and their constituents [6]. The inhibition effect of some trees cultivated in arid regions, against the corrosion of steel reinforcement in an alkaline chloride solution, has been evaluated by Etteyeb et al. [7].

Mott-Schottky analysis showed the formation of a passive layer on the metallic surface. EIS results suggest an increase in carbon steel corrosion resistance, in the plants extract presence, comparatively to the blank systems. Furthermore, SEM and EDS analyses corroborate these results.

An eco-friendly inhibitor for mild steel corrosion made from Pennisetum purpureum biomass and synergistic intensifiers has been formulated by Ituen et al. [8]. Kinetic data treatment indicated an increase in the energy barrier by intensifier ions. The results demonstrate that elephant grass extract, blended with halide ions, can act as an alternative eco-friendly inhibitor for mild steel, at elevated temperatures.

Dos Santos et al. have investigated carbon steel corrosion inhibition in acidic chloride by Mangiferin. The results showed that carbon steel exposed to this medium containing Mangiferin had a reduction in the mass loss process and a higher electrochemical behavior, relatively to the carbon steel samples exposed to the same medium, in Mangiferin absence. These results suggest that Mangiferin shows an inhibitory action on the carbon steel corrosion process, in the studied conditions [9].

Umoren et al. have evaluated mustard seed extract (MSE) as an eco-friendly corrosion inhibitor for X60 steel in acidic media [10]. The obtained results show that MSE inhibited steel corrosion in both media, which was more pronounced in $\mathrm{H}_{2} \mathrm{SO}_{4}$ than in $\mathrm{HCl}$ environments. The inhibition efficiency increased with higher extract concentrations, but decreased with increased temperatures. The potentiodynamic polarization studies revealed that MSE functions as a mixedtype inhibitor. The corrosion inhibition is assumed to occur via adsorption of the extract components onto the steel surface, which was found to obey Langmuir adsorption isotherm model. The morphology of the corroding steel surface, in the absence and presence of the mustard seed extract, was visualized using scanning electron microscopy. Rajendran et al. have used extracts of various plant 
materials, such as henna leaves, curcumin, caffeine and spirulina, to control metals corrosion [11-36].

The present work was undertaken to evaluate the inhibition efficiency of an aqueous extract of Commelina benghalensis leaves against mild steel corrosion in hydrochloric acid and sulphuric acid media. Weight loss and electrochemical methods, such as polarization study and AC impedance spectra, have been used.

\section{Materials and methods}

The extract of Commelina benghalensis leaves was used as corrosion inhibitor in the present study. The leaves and flowers of Commelina benghalensis are shown in Fig. 1.

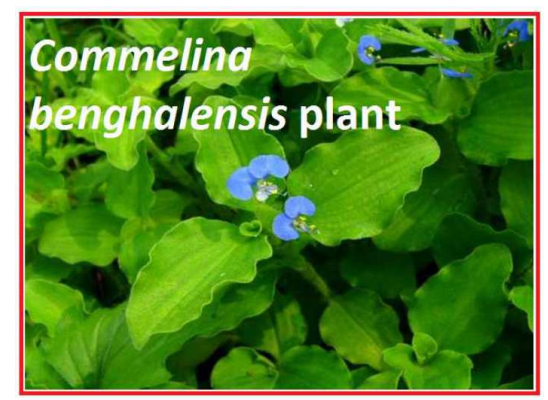

Figure 1. Commelina benghalensis plant.

The botanical details of Commelina benghalensis are given below: it belongs to the Commelinaceae family. The Tamil name is "Kanavazhiain". In China, it is used as a medicinal herb that is said to have diuretic, febrifugal and antiinflammatory effects, while in Pakistan it is used to cure skin swellings, leprosy, and as a laxative.

The phyto-chemical screening of Commelina benghalensis leaves extract is given in Table 1 [37].

Table 1. Phyto-chemical screening of Commelina benghalensis leaves extract.

\begin{tabular}{|l|c|c|c|c|}
\hline $\begin{array}{c}\text { Phyto-chemical } \\
\text { constituents }\end{array}$ & Aqueous & Methanol & Hexane & CCl4 $^{-1}$ \\
\hline Flavonoids & + & - & - & - \\
\hline Alkaloids & - & - & ++++ & ++++ \\
\hline Glycosides & - & - & - & - \\
\hline Steroids & - & - & - & - \\
\hline Total Phenols and Tannins & + & + & - & - \\
\hline Triterphenoids & - & - & - & - \\
\hline Saponins & ++ & - & - & - \\
\hline Proteins and amino acids & +++ & +++ & - & - \\
\hline Anthraquinones & - & - & - & - \\
\hline \multicolumn{2}{|l|}{$-=$ absent; + = present; ++ moderately present; +++ = appreciable amount } \\
\hline
\end{tabular}

Preliminary phyto-chemical screening mainly revealed the presence of saponins, phenols, flavonoids, alkaloids, tannins, proteins and amino acids. 


\section{Extract preparation}

\section{Cold percolation method}

The leaves were collected, shade dried and powdered. About $1 \mathrm{~g}$ of the powdered leaves was macerated with $1000 \mathrm{~mL}$ of double distilled water, tightly covered with aluminium foil, and kept for $24 \mathrm{hrs}$. After $24 \mathrm{hrs}$, the macerated extract was filtered by a Whatmann filter paper. From the extract, the various concentrations were prepared.

\section{Used materials and chemicals}

Mild steel specimens (Wt \%: $0.026 \%-\mathrm{S}, 0.06 \%-\mathrm{P}, 0.4 \%-\mathrm{Mn}, 0.1 \%-\mathrm{C}$, and the remainder iron) with the dimensions $1 \times 5 \times 0.2 \mathrm{~cm}$ were abraded to mirror finish, degreased with acetone, and used for the weight loss method.

For the polarization study, a cylindrical mild steel rod embedded in Teflon, with an exposed area of $1 \mathrm{~cm}^{2}$, was used. The electrodes were abraded with emery papers of $0 / 0,2 / 0,3 / 0$, and 4/0 grades, degreased with acetone, dried and used.

\section{Weight loss method}

Weight loss measurements were performed in $1 \mathrm{M} \mathrm{HCl}$ and $0.5 \mathrm{M} \mathrm{H}_{2} \mathrm{SO}_{4}$, with and without the inhibitor presence. Inhibition efficiencies for various inhibitor concentrations were calculated using the relation:

$$
\text { Inhibition efficiency }(\%)=\mathrm{W}_{0}-\mathrm{W}_{\mathrm{i}} / \mathrm{W}_{0} \times 100
$$

where $\mathrm{W}_{0}=$ weight loss in blank and $\mathrm{W}_{\mathrm{i}}=$ weight loss in the inhibitor presence.

\section{Electrochemical studies}

The polarization study and AC impedance spectra were recorded in a potentiostat. The experiments were recorded in a three electrodes cell assembly, which is shown in Scheme 1.



Scheme 1. Three electrodes cell.

Mild steel was used as working electrode. A saturated calomel electrode (SCE) was used as reference electrode. A platinum foil $\left(2 \mathrm{~cm}^{2}\right)$ was used as counter electrode. The used working electrode was a mild steel rod of the same composition, embedded in araldite, and with an exposed area of $1 \mathrm{~cm}^{2}$. 
From the potentiodynamic polarization study, the corrosion current, corrosion potential and the Tafel slopes were derived. From AC impedance spectra, the charge transfer resistance and double layer capacitance were calculated.

The counter electrode area is much larger compared to the working electrode area. This will exert a uniform potential field on the working electrode.

$100 \mathrm{~mL}$ of the test solution were taken in a polarization cell. The working electrode was successively abraded with $0 / 0,1 / 0,2 / 0,3 / 0$, and 4/0 emery papers, and degreased with acetone. The working electrode, reference and auxiliary platinum electrodes were assembled, and connections were made. Stirring was provided to the test solutions, to avoid the system concentrations polarization before the experiment start. A time interval of about 30 min was given for the system to attain its state, and open circuit potential was recorded.

\section{Results and discussion Weight loss studies}

The inhibition efficiency of Commelina benghalensis leaves extract in controlling mild steel corrosion in $0.5 \mathrm{M} \mathrm{H}_{2} \mathrm{SO}_{4}$ has been evaluated by the weight loss method.

Tables 2 and 3 give the inhibition efficiency of different concentrations of Commelina benghalensis leaves extract in $1 \mathrm{~N} \mathrm{HCl}$ and $0.5 \mathrm{M} \mathrm{H} \mathrm{H}_{2} \mathrm{SO}_{4}$, respectively. It was observed that, as the inhibitor concentration increased, the inhibition efficiency also increased. $900 \mathrm{ppm}$ of inhibitor offered $93.40 \%$ inhibition efficiency in $1 \mathrm{~N} \mathrm{HCl}$, and $85.71 \%$ in $0.5 \mathrm{M} \mathrm{H}_{2} \mathrm{SO}_{4}$.

Table 2. Inhibition effect of mild steel corrosion in $1 \mathrm{~N} \mathrm{HCl}$, using Commelina benghalensis leaves extract.

\begin{tabular}{|c|c|c|}
\hline $\begin{array}{c}\text { [Inhibitor] } \\
\text { (ppm) }\end{array}$ & $\begin{array}{c}\text { Rate of corrosion } \\
\left(\mathbf{g} \mathbf{~ c m}^{-\mathbf{2}} \mathbf{h}^{\mathbf{- 1}}\right)\end{array}$ & $\begin{array}{c}\text { Inhibition } \\
\text { efficiency } \mathbf{( \% )}\end{array}$ \\
\hline Blank & 0.000183 & - \\
\hline 100 & 0.000152 & 17.27 \\
\hline 200 & 0.000138 & 24.55 \\
\hline 300 & 0.000130 & 29.09 \\
\hline 400 & 0.000102 & 44.55 \\
\hline 500 & 0.000082 & 55.45 \\
\hline 600 & 0.000060 & 67.27 \\
\hline 700 & 0.000042 & 77.27 \\
\hline 800 & 0.000028 & 84.55 \\
\hline 900 & 0.000010 & 93.40 \\
\hline
\end{tabular}

\section{Adsorption isotherms}

Adsorption isotherms are usually used to describe the adsorption process. Adsorption isotherms are very important to determine the organoelectrochemical reaction mechanism. The most frequently used isotherms include: Langmuir, Temkin, Flory-Huggins, and the recently formulated thermodynamic/kinetic model of El-Awady et al. The use of adsorption isotherms that describe the adsorption of a corrosion inhibitor can provide important clues about the nature of the metal-inhibitor interaction. Adsorption of the organic molecules occurs when the interaction energy between the molecules 
and the metal surface is higher than that between the $\mathrm{H}_{2} \mathrm{O}$ molecules and the metal surface. It is important to know the-adsorption mode, to understand this part of the study.

Table 3. Inhibition effect of mild steel corrosion in $0.5 \mathrm{M} \mathrm{H}_{2} \mathrm{SO}_{4}$, using Commelina benghalensis leaves extract.

\begin{tabular}{|c|c|c|}
\hline $\begin{array}{c}\text { [Inhibitor] } \\
(\mathbf{p p m})\end{array}$ & $\begin{array}{c}\text { Rate of corrosion } \\
\left(\mathbf{g ~ c m}^{-\mathbf{2}} \mathbf{h} \mathbf{-}\right)\end{array}$ & $\begin{array}{c}\text { Inhibition } \\
\text { efficiency } \mathbf{( \% )}\end{array}$ \\
\hline Blank & 0.000093 & - \\
\hline 100 & 0.000085 & 8.92 \\
\hline 200 & 0.000075 & 19.64 \\
\hline 300 & 0.000065 & 30.35 \\
\hline 400 & 0.000062 & 33.92 \\
\hline 500 & 0.000042 & 55.35 \\
\hline 600 & 0.000035 & 62.50 \\
\hline 700 & 0.000028 & 69.64 \\
\hline 800 & 0.000018 & 80.35 \\
\hline 900 & 0.000013 & 85.71 \\
\hline
\end{tabular}

\section{Langmuir isotherm}

In order to obtain the adsorption isotherm, the degree of surface coverage $(\theta)$ for various inhibitor concentrations has been calculated according to its equation. Langmuir isotherm was tested for its fit to the experimental data. Langmuir isotherm is given by:

$$
\mathrm{C} / \Theta=1 / \mathrm{K}_{\mathrm{ads}}+\mathrm{C}
$$

where $\Theta$ is the degree of surface coverage, $\mathrm{C}$ is the molar inhibitor in the bulk solution and $\mathrm{K}_{\mathrm{ads}}$ is the equilibrium constant of the adsorption process.

Table 4. Langmuir adsorption isotherm for mild steel corrosion inhibition in $1 \mathrm{~N} \mathrm{HCl}$, using Commelina benghalensis leaves extract.

\begin{tabular}{|c|c|c|c|}
\hline $\begin{array}{c}\text { [Inhibitor] } \\
(\mathbf{p p m})\end{array}$ & $\boldsymbol{\theta} /(\mathbf{1 - \theta})$ & $3+\log \theta /(1-\theta)$ & $3+\log C$ \\
\hline Blank & - & - & - \\
\hline 100 & 0.2088 & 2.3197 & 5.0000 \\
\hline 200 & 0.3253 & 2.5123 & 5.3010 \\
\hline 300 & 0.4103 & 2.6131 & 5.4771 \\
\hline 400 & 0.8033 & 2.9049 & 5.6021 \\
\hline 500 & 1.2449 & 3.0951 & 5.6990 \\
\hline 600 & 2.0556 & 3.3129 & 5.7782 \\
\hline 700 & 3.4000 & 3.5315 & 5.8451 \\
\hline 800 & 5.4706 & 3.7380 & 5.9031 \\
\hline 900 & 14.1500 & 4.1507 & 5.9542 \\
\hline
\end{tabular}

Langmuir isotherm assumes that the metal surface contains a fixed number of adsorption sites, and that each site holds one adsorbate; $\Delta \mathrm{G}^{0}$ ads is the same for all sites, and it is independent from $\Theta$; the adsorbates do not interact with each other, i.e., there is no effect of the adsorbates lateral interaction on $\Delta \mathrm{G}^{0}$ ads. It is important to know this part of the study. Tables 4 and 5 show that the obtained values were fitted to Langmuir isotherm, and the best fit to the experimental data was obtained. 
Table 5. Langmuir adsorption isotherm for mild steel corrosion inhibition in $0.5 \mathrm{M}$ $\mathrm{H}_{2} \mathrm{SO}_{4}$, using Commelina benghalensis leaves extract.

\begin{tabular}{|c|c|c|c|}
\hline $\begin{array}{c}\text { [Inhibitor] } \\
\text { (ppm) }\end{array}$ & $\boldsymbol{\theta} /(\mathbf{1 - \theta})$ & $3+\log \theta /(1-\theta)$ & $3+\log C$ \\
\hline Blank & - & - & - \\
\hline 100 & 0.0980 & 1.9914 & 5.0000 \\
\hline 200 & 0.2444 & 2.3882 & 5.3010 \\
\hline 300 & 0.4359 & 2.6394 & 5.4771 \\
\hline 400 & 0.5135 & 2.7106 & 5.6021 \\
\hline 500 & 1.2400 & 3.0934 & 5.6990 \\
\hline 600 & 1.6667 & 3.2218 & 5.7782 \\
\hline 700 & 2.2941 & 3.3606 & 5.8451 \\
\hline 800 & 4.0909 & 3.6118 & 5.9031 \\
\hline 900 & 6.0000 & 3.7782 & 5.9542 \\
\hline
\end{tabular}

The plot of $\log \log \Theta /(1-\Theta)$ vs. $\log \mathrm{C}$ is a straight line as shown in Figs. 2 and 3. Thus, the Langmuir isotherm is valid for the inhibitor.

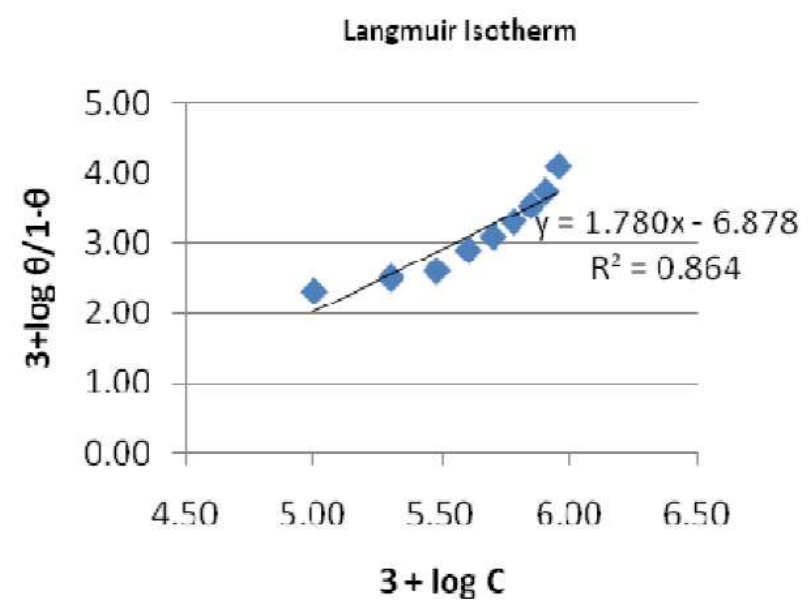

Figure 2. Langmuir adsorption isotherm for mild steel corrosion inhibition in $1 \mathrm{~N} \mathrm{HCl}$, using Commelina benghalensis leaves extract.

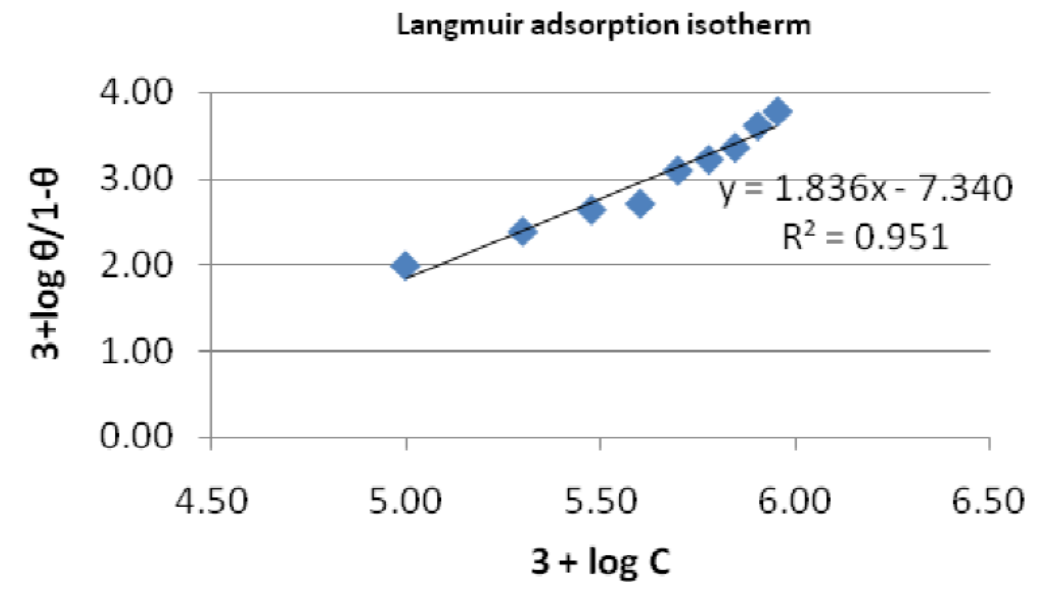

Figure 3. Langmuir adsorption isotherm for mild steel corrosion inhibition in $0.5 \mathrm{M}$ $\mathrm{H}_{2} \mathrm{SO}_{4}$, using Commelina benghalensis leaves extract. 


\section{Temkin adsorption isotherm}

The Temkin adsorption isotherm is given by the expression:

$$
\theta=-2.303 \log \mathrm{K} / 2 \mathrm{a}-2.303 \log \mathrm{C} / 2 \mathrm{a}
$$

where ' $\mathrm{K}$ ' is the adsorption equilibrium constant, and ' $\mathrm{a}$ ' is the lateral interaction parameter. Tables 6 and 7 show the Temkin isotherm values, and Figs. 4 and 5 show the plots of $(2+\log C)$ against $\theta$, at various temperatures. The linear plot indicates that Temkin adsorption isotherm was obeyed, and ' $a$ ' negative value indicated repulsion in the adsorption layer.

Table 6. Temkin adsorption isotherm for mild steel corrosion inhibition in $1 \mathrm{~N} \mathrm{HCl}$, using Commelina benghalensis leaves extract.

\begin{tabular}{|c|c|c|}
\hline $\begin{array}{c}\text { [Inhibitor] } \\
\quad(\mathbf{p p m})\end{array}$ & $2+\log C$ & $\boldsymbol{\theta}$ \\
\hline 100 & 4.0000 & 0.1727 \\
\hline 200 & 4.3010 & 0.2455 \\
\hline 300 & 4.4771 & 0.2909 \\
\hline 400 & 4.6021 & 0.4455 \\
\hline 500 & 4.6990 & 0.5545 \\
\hline 600 & 4.7782 & 0.6727 \\
\hline 700 & 4.8451 & 0.7727 \\
\hline 800 & 4.9031 & 0.8455 \\
\hline 900 & 4.9542 & 0.9340 \\
\hline
\end{tabular}

Table 7. Temkin adsorption isotherm for mild steel corrosion inhibition in $0.5 \mathrm{M}$ $\mathrm{H}_{2} \mathrm{SO}_{4}$, using Commelina benghalensis leaves extract.

\begin{tabular}{|c|c|c|}
\hline $\begin{array}{c}\text { [Inhibitor] } \\
\text { (ppm) }\end{array}$ & 2+log $\mathbf{C}$ & $\boldsymbol{\theta}$ \\
\hline 100 & 4.0000 & 0.0893 \\
\hline 200 & 4.3010 & 0.1964 \\
\hline 300 & 4.4771 & 0.3036 \\
\hline 400 & 4.6021 & 0.3393 \\
\hline 500 & 4.6990 & 0.5536 \\
\hline 600 & 4.7782 & 0.6250 \\
\hline 700 & 4.8451 & 0.6964 \\
\hline 800 & 4.9031 & 0.8036 \\
\hline 900 & 4.9542 & 0.8571 \\
\hline
\end{tabular}

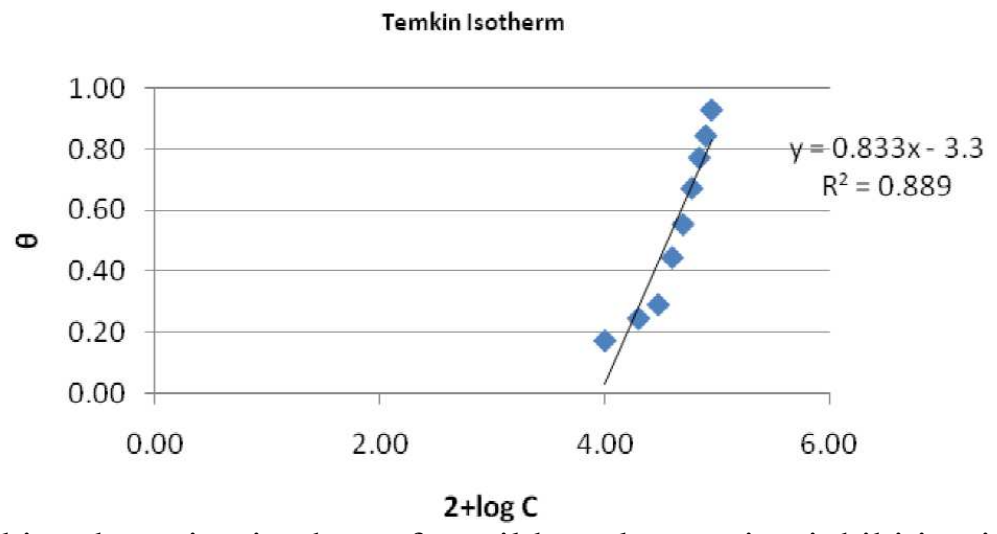

Figure 4. Temkin adsorption isotherm for mild steel corrosion inhibition in $1 \mathrm{~N} \mathrm{HCl}$, using Commelina benghalensis leaves extract. 


\section{Flory-Huggins adsorption isotherm}

Flory-Huggins adsorption isotherm is given by the expression,

$$
\log \theta / c=\log K+x \log (1-\theta)
$$

where ' $\mathrm{x}$ ' is the size parameter, and it is a measure of the number of adsorbed water molecules substituted by an inhibitor molecule. Tables 8 and 9 and the linear plot of $3+\log \Theta / C$ against $3+\log (1-\Theta)$ (Figs. 6 and 7$)$ show that FloryHuggins isotherm was obeyed.



Figure 5. Temkin adsorption isotherm for mild steel corrosion inhibition in $0.5 \mathrm{M}$ $\mathrm{H}_{2} \mathrm{SO}_{4}$, using Commelina benghalensis leaves extract.

Table 8. Flory-Huggins adsorption isotherm for mild steel corrosion inhibition in $1 \mathrm{~N}$ $\mathrm{HCl}$, using Commelina benghalensis leaves extract.

\begin{tabular}{|c|c|c|c|c|c|}
\hline $\boldsymbol{\theta}$ & {$[\mathrm{C}],(\mathrm{ppm})$} & $\Theta / C$ & $3+\log \theta / C$ & $1-\theta$ & $3+\log (1-\theta)$ \\
\hline 0.1727 & 100 & 0.0017 & 0.2374 & 0.8273 & 2.9176 \\
\hline 0.2455 & 200 & 0.0012 & 0.0889 & 0.7545 & 2.8777 \\
\hline 0.2909 & 300 & 0.0010 & 0.0734 & 0.7091 & 2.8507 \\
\hline 0.4455 & 400 & 0.0011 & 0.0467 & 0.5545 & 2.7439 \\
\hline 0.5545 & 500 & 0.0011 & 0.0450 & 0.4455 & 2.6488 \\
\hline 0.6727 & 600 & 0.0011 & 0.0497 & 0.3273 & 2.5149 \\
\hline 0.7727 & 700 & 0.0011 & 0.0429 & 0.2273 & 2.3565 \\
\hline 0.8455 & 800 & 0.0011 & 0.0240 & 0.1545 & 2.1891 \\
\hline 0.9340 & 900 & 0.0010 & & 0.1000 & 2.0000 \\
\hline
\end{tabular}

Table 9. Flory-Huggins adsorption isotherm for mild steel corrosion inhibition in $0.5 \mathrm{M} \mathrm{H}_{2} \mathrm{SO}_{4}$, using Commelina benghalensis leaves extract.

\begin{tabular}{|c|c|c|c|c|c|c|}
\hline S. no & $\theta$ & $\mathrm{C}$ & $\theta / \mathrm{C}$ & $3+\log \theta / C$ & $1-\theta$ & $3+\log (1-\theta)$ \\
\hline 1 & 0.0893 & 100 & 0.0009 & 0.9493 & 0.9107 & 2.9594 \\
\hline 2 & 0.1964 & 200 & 0.0010 & 0.9912 & 0.8036 & 2.9050 \\
\hline 3 & 0.3036 & 300 & 0.0010 & 1.0000 & 0.6964 & 2.8429 \\
\hline 4 & 0.3393 & 400 & 0.0008 & 0.9242 & 0.6607 & 2.8200 \\
\hline 5 & 0.5536 & 500 & 0.0011 & 1.0413 & 0.4464 & 2.6498 \\
\hline 6 & 0.6250 & 600 & 0.0010 & 1.0000 & 0.3750 & 2.5740 \\
\hline 7 & 0.6964 & 700 & 0.0010 & 0.9956 & 0.3036 & 2.4823 \\
\hline 8 & 0.8036 & 800 & 0.0010 & 1.0000 & 0.1964 & 2.2932 \\
\hline 9 & 0.8571 & 900 & 0.0010 & 0.9777 & 0.1429 & 2.1549 \\
\hline
\end{tabular}




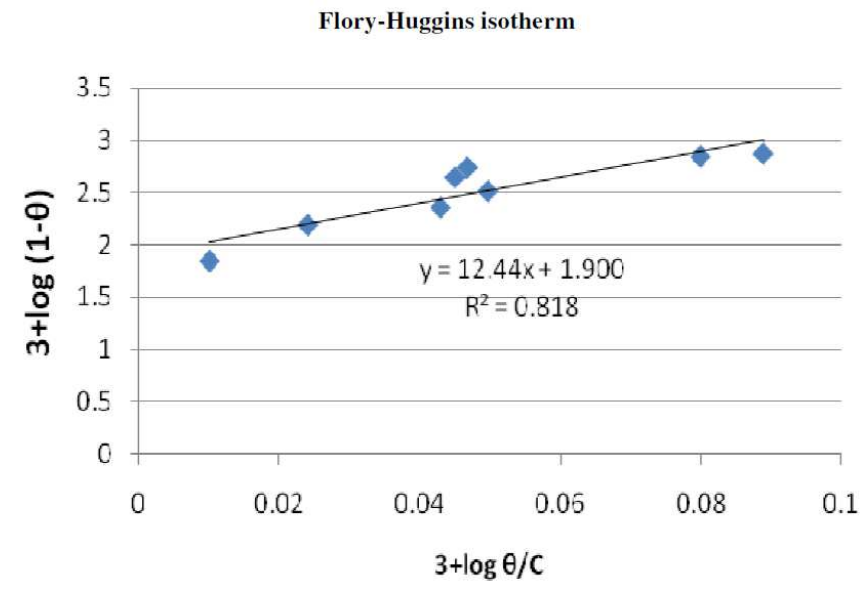

Figure 6. Flory-Huggins adsorption isotherm for mild steel corrosion inhibition in $1 \mathrm{~N} \mathrm{HCl}$, using Commelina benghalensis leaves extract.

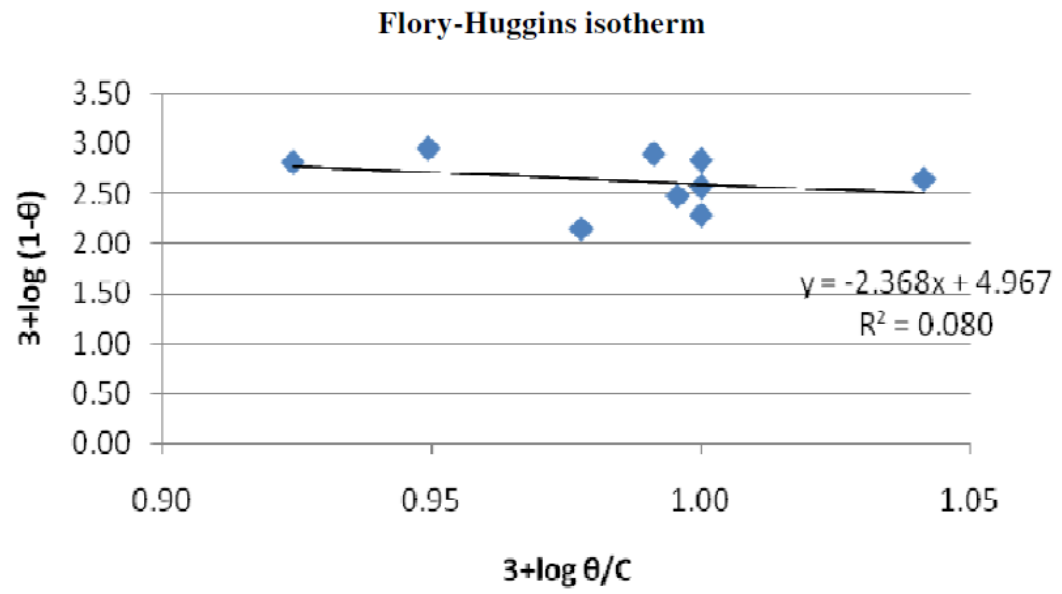

Figure 7. Flory-Huggins adsorption isotherm for mild steel corrosion inhibition in $0.5 \mathrm{M} \mathrm{H}_{2} \mathrm{SO}_{4}$, using Commelina benghalensis leaves extract.

Table 10. El-Awady adsorption isotherm for mild steel corrosion inhibition in $1 \mathrm{~N} \mathrm{HCl}$, using Commelina benghalensis leaves extract.

\begin{tabular}{|c|c|c|c|c|c|}
\hline $\begin{array}{c}{[\mathrm{C}]} \\
\text { ppm }\end{array}$ & $2+\log C$ & $\theta$ & $1-\theta$ & $\boldsymbol{\theta} / \mathbf{1}-\boldsymbol{\theta}$ & $2+\log (\boldsymbol{\theta} / 1-\theta)$ \\
\hline 100 & 4.0000 & 0.1727 & 0.8273 & 0.2088 & 1.3197 \\
\hline 200 & 4.3010 & 0.2455 & 0.7545 & 0.3253 & 1.5123 \\
\hline 300 & 4.4771 & 0.2909 & 0.7091 & 0.4103 & 1.6131 \\
\hline 400 & 4.6021 & 0.4455 & 0.5545 & 0.8033 & 1.9049 \\
\hline 500 & 4.6990 & 0.5545 & 0.4455 & 1.2449 & 2.0951 \\
\hline 600 & 4.7782 & 0.6727 & 0.3273 & 2.0556 & 2.3129 \\
\hline 700 & 4.8451 & 0.7727 & 0.2273 & 3.4000 & 2.5315 \\
\hline 800 & 4.9031 & 0.8455 & 0.1545 & 5.4706 & 2.7380 \\
\hline 900 & 4.9542 & 0.9340 & 0.0660 & 14.1515 & 3.1508 \\
\hline
\end{tabular}

\section{El-Awady isotherm}

El-Awady isotherm is given by the expression:

$$
\log (\theta / 1-\theta)=\log \mathrm{K}_{\mathrm{ads}}+\mathrm{y} \log \mathrm{C}
$$


where $\mathrm{K}_{\mathrm{ads}}$ is the equilibrium constant of the adsorption process, calculated by the relationship, $K_{\mathrm{ads}}=1 / \mathrm{k}$. Tables 10 and 11 , and a linear plot of $2+\log (\theta / 1-\theta)$ against $2+\log \mathrm{C}$ (Figs. 8 and 9), show that El-Awady isotherm was obeyed.

Table 11. El-Awady adsorption isotherm for mild steel corrosion inhibition in $0.5 \mathrm{M}$ $\mathrm{H}_{2} \mathrm{SO}_{4}$, using Commelina benghalensis leaves extract.

\begin{tabular}{|c|c|c|c|c|c|}
\hline $\begin{array}{c}{[\mathbf{C}]} \\
\text { ppm }\end{array}$ & $2+\log C$ & $\boldsymbol{\theta}$ & $1-\theta$ & $\theta / 1-\theta$ & $2+\log (\boldsymbol{\theta} / 1-\theta)$ \\
\hline 100 & 4.0000 & 0.0893 & 0.9107 & 0.0980 & 0.9914 \\
\hline 200 & 4.3010 & 0.1964 & 0.8036 & 0.2444 & 1.3882 \\
\hline 300 & 4.4771 & 0.3036 & 0.6964 & 0.4359 & 1.6394 \\
\hline 400 & 4.6021 & 0.3393 & 0.6607 & 0.5135 & 1.7106 \\
\hline 500 & 4.6990 & 0.5536 & 0.4464 & 1.2400 & 2.0934 \\
\hline 600 & 4.7782 & 0.6250 & 0.3750 & 1.6667 & 2.2218 \\
\hline 700 & 4.8451 & 0.6964 & 0.3036 & 2.2941 & 2.3606 \\
\hline 800 & 4.9031 & 0.8036 & 0.1964 & 4.0909 & 2.6118 \\
\hline 900 & 4.9 & 0.8 & 29 & 6.0000 & 82 \\
\hline
\end{tabular}

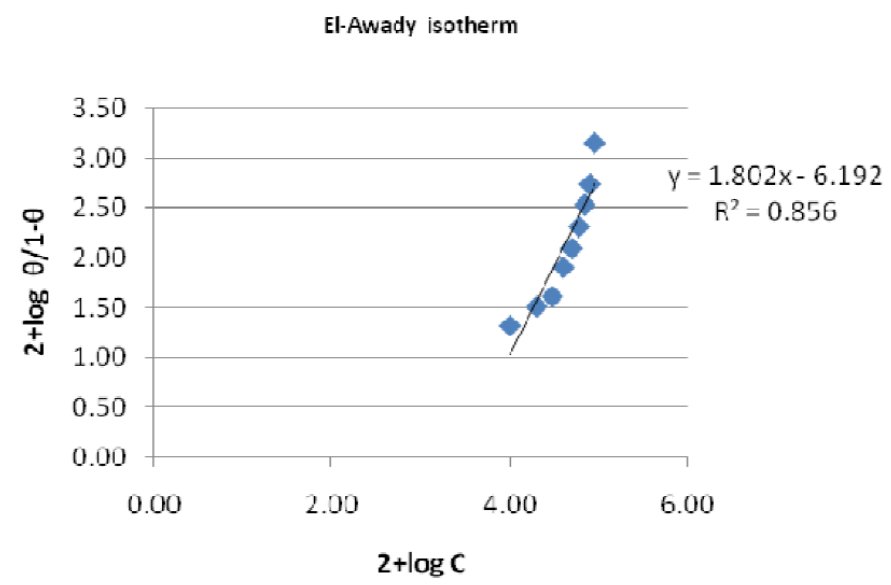

Figure 8. El-Awady adsorption isotherm for mild steel corrosion inhibition in $1 \mathrm{~N} \mathrm{HCl}$, using Commelina benghalensis leaves extract.

\section{Free energy change}

The inhibitor's free energy change of adsorption $\left(\Delta \mathrm{G}^{0}{ }_{\mathrm{ads}}\right)$ onto mild steel surfaces was related to the adsorption constant, according to the equation:

$$
\Delta \mathrm{G}_{\text {ads }}^{0}=-2.303 \mathrm{RT} \log \left(\mathrm{K}_{\mathrm{ads}} \times 55.5\right)
$$

From the results, showed in Tables 12 and 13, $\Delta \mathrm{G}^{0}$ ads values were found to be negative, and were below the threshold value of $-40 \mathrm{~kJ} / \mathrm{mol}$, indicating that the adsorption of Commelina benghalensis onto a mild steel surface is spontaneous, and that the physical adsorption mechanism is applicable. 


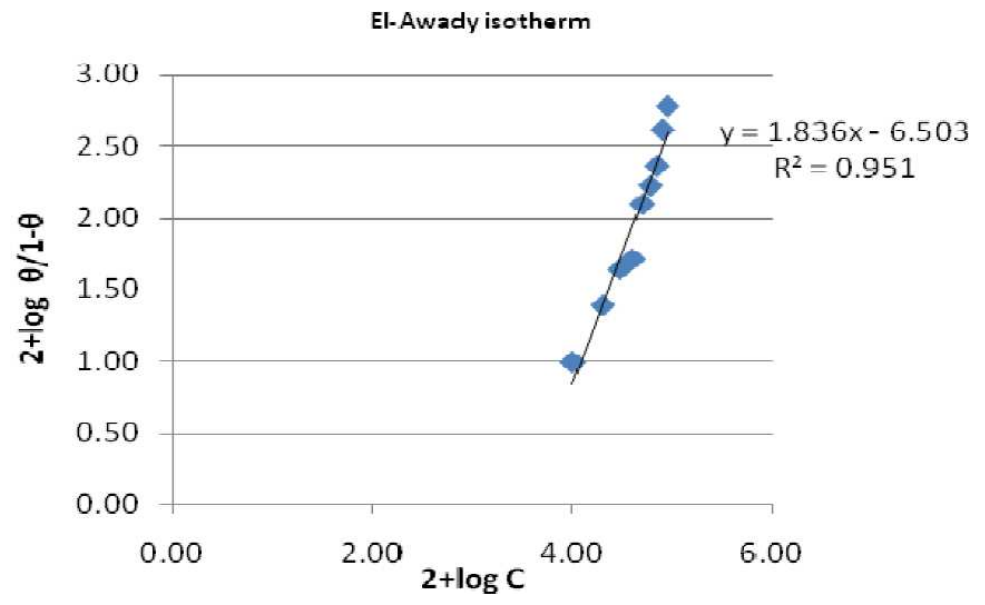

Figure 9. El-Awady adsorption isotherm for mild steel corrosion inhibition in $0.5 \mathrm{M}$ $\mathrm{H}_{2} \mathrm{SO}_{4}$, using Commelina benghalensis leaves extract.

Table 12. Adsorption isotherms parameter for mild steel corrosion inhibition in $1 \mathrm{~N}$ $\mathrm{HCl}$, using Commelina benghalensis leaves extract.

\begin{tabular}{|c|c|c|c|c|c|c|}
\hline \multirow{2}{*}{ System } & Isotherm & $\Delta \mathbf{G}^{\mathbf{0}}$ ads & Slope & $\mathbf{R}^{\mathbf{2}}$ & $\mathbf{a}$ & $\mathbf{1 / y}$ \\
\hline \multirow{2}{*}{$\begin{array}{c}\text { Commelina } \\
\text { benghalensis } \\
\text { leaves extract }\end{array}$} & Langmuir & -1481.35 & 1.780 & 0.864 & - & 0.561 \\
\cline { 2 - 7 } & Temkin & -3087.50 & 0.833 & 0.889 & - & 1.200 \\
\cline { 2 - 7 } & Flory-Huggins & -5362.50 & -2.882 & 0.872 & - & -0.109 \\
\hline
\end{tabular}

Table 13. Adsorption isotherms parameter for mild steel corrosion inhibition in $0.5 \mathrm{M} \mathrm{H}_{2} \mathrm{SO}_{4}$, using Commelina benghalensis leaves extract.

\begin{tabular}{|c|c|c|c|c|c|c|}
\hline \multirow{2}{*}{ System } & Isotherm & $\Delta \mathbf{G}^{\mathbf{0}}$ ads & Slope & $\mathbf{R}^{\mathbf{2}}$ & $\mathbf{a}$ & $\mathbf{1} / \mathbf{y}$ \\
\hline \multirow{2}{*}{$\begin{array}{c}\text { Commelina } \\
\text { benghalensis } \\
\text { leaves extract }\end{array}$} & Langmuir & -5747.61 & -7.340 & 0.951 & - & -0.136 \\
\cline { 2 - 7 } & Temkin & -3011.75 & -3.383 & 0.915 & -0.399 & -0.295 \\
\cline { 2 - 7 } & Flory-Huggins & -2051.29 & 4.967 & 0.080 & - & 0.201 \\
\cline { 2 - 7 } & El-Awady & -1566.80 & -6.503 & 0.951 & - & -0.153 \\
\hline
\end{tabular}

\section{Potentiodynamic polarization studies}

The polarization study has been used to investigate the formation of a protective film during the corrosion inhibition study. Whenever there is corrosion inhibition, the corrosion current value decreases [38-42].

Tables 14 and 15 and Figs. 10 to 15 give the potentiodynamic parameter values, such as corrosion current $\left(\mathrm{I}_{\text {corr }}\right)$, corrosion potential $\left(\mathrm{E}_{\mathrm{corr}}\right)$ and the cathodic Tafel slopes (bc and ba) for the different concentrations shown in the green inhibitor under study. It can be seen that the active principles present in the extract have been adsorbed onto the metal surface. When the inhibitor concentration is 100 ppm, the system functions as a mixed type inhibitor, because the shift in corrosion potential is within $80 \mathrm{mV}$. However, at higher concentrations $(900$ ppm), the system functions as a cathodic type inhibitor, because the shift in the corrosion potential is towards the cathodic side (more negative). 
Table 14. Corrosion parameters obtained from polarization curves for mild steel in $1 \mathrm{~N}$ $\mathrm{HCl}$, in the inhibitor presence and absence.

\begin{tabular}{|c|c|c|c|c|c|c|}
\hline System & $\begin{array}{c}\text { [Inhibitor] } \\
\text { ppm }\end{array}$ & $\begin{array}{c}\text { Icorr } \\
\mathrm{mA} / \mathrm{cm}^{2}\end{array}$ & $\begin{array}{c}\text {-Ecorr } \\
\text { mV vs. SCE }\end{array}$ & $\begin{array}{c}\text { ba. } \\
\text { mV dec }\end{array}$ & $\begin{array}{c}\text { bc. } \\
\text { mV dec }{ }^{-1}\end{array}$ & $\begin{array}{c}\text { Inhibition } \\
\text { efficiency }(\%)\end{array}$ \\
\hline Blank & - & 397.558 & 484.372 & 195.4 & 184.6 & - \\
\hline \multirow{2}{*}{$\begin{array}{c}\text { Commelina } \\
\text { benghalensis } \\
\text { leaves extract }\end{array}$} & 100 & 326.066 & 526.778 & 157.1 & 151.5 & 17.98 \\
\hline & 900 & 21.095 & 597.158 & 104.8 & 122.5 & 94.69 \\
\hline
\end{tabular}

Table 15. Corrosion parameters obtained from polarization curves for mild steel in $0.5 \mathrm{M} \mathrm{H}_{2} \mathrm{SO}_{4}$, in the inhibitor presence and absence.

\begin{tabular}{|l|c|c|c|c|c|c|}
\hline \multicolumn{1}{|c|}{ System } & $\begin{array}{c}\text { [nhibitor }] \\
\mathbf{p p m}\end{array}$ & $\begin{array}{c}\mathbf{I} \text { Icorr } \\
\mathbf{m A} / \mathbf{c m}^{\mathbf{2}}\end{array}$ & $\begin{array}{c}-\mathbf{E} \text { corr } \\
\mathbf{m V} \mathbf{~ v s . ~ S C E}\end{array}$ & $\begin{array}{c}\mathbf{b a} \\
\mathbf{m V ~ d e c}^{-\mathbf{1}}\end{array}$ & $\begin{array}{c}\mathbf{b c} \\
\mathbf{m V ~ d e c}^{-\mathbf{-}}\end{array}$ & $\begin{array}{c}\text { Inhibition } \\
\text { efficiency (\%) }\end{array}$ \\
\hline Blank & - & 249.310 & 490.236 & 185.3 & 198.2 & - \\
\hline $\begin{array}{l}\text { Commelina } \\
\text { benghalensis }\end{array}$ & 100 & 218.979 & 515.727 & 167.0 & 186.2 & 8.15 \\
\cline { 2 - 7 } & 900 & 33.39 & 575.930 & 134.1 & 173.2 & 86.60 \\
\hline
\end{tabular}

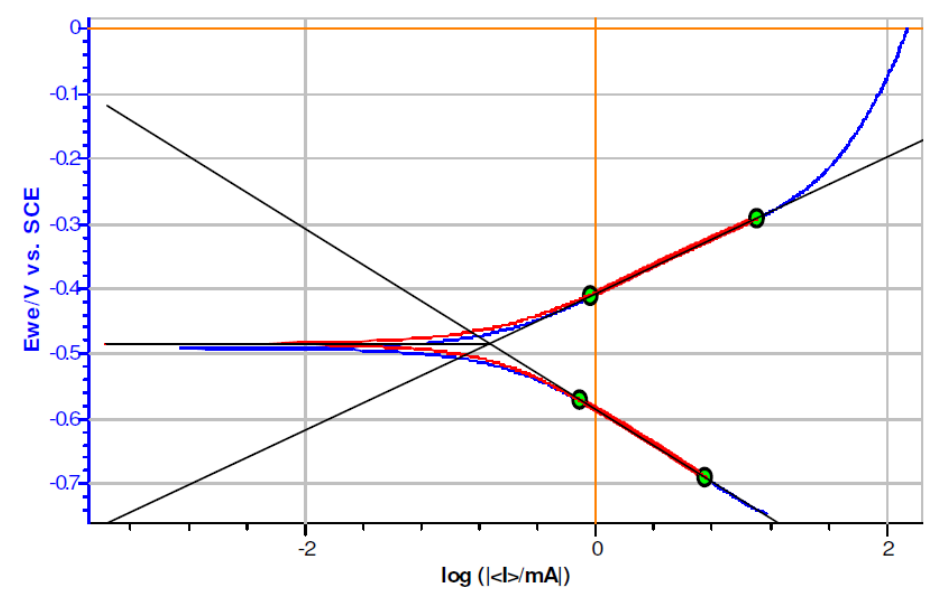

Figure 10. Potentiometric polarization curve for $1 \mathrm{~N} \mathrm{HCl}$ medium.

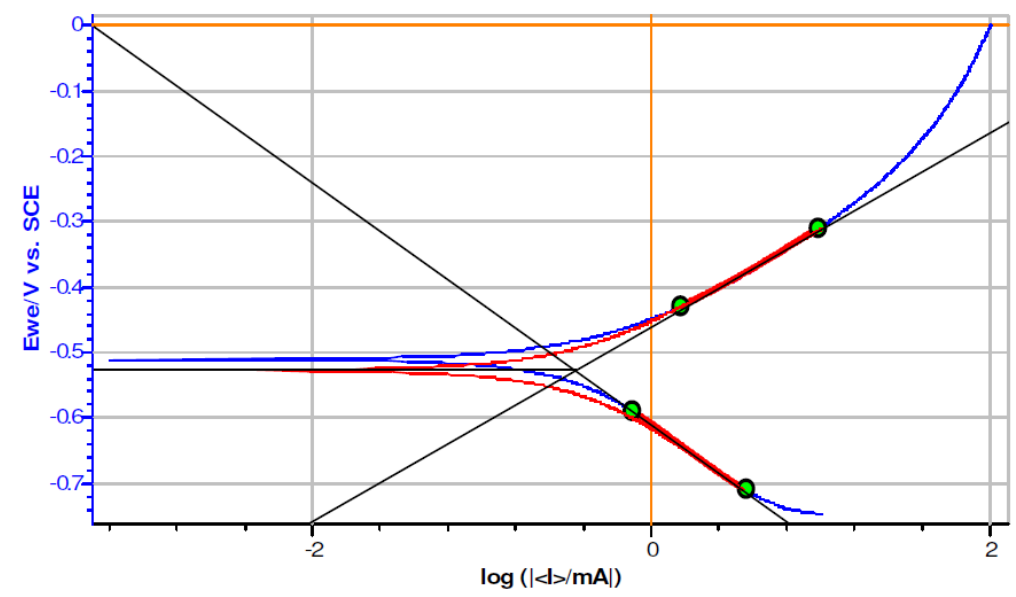

Figure 11. Potentiometric polarization curve for $1 \mathrm{~N} \mathrm{HCl}$ medium, in the presence of 100 ppm concentration of Commelina benghalensis leaves extract. 


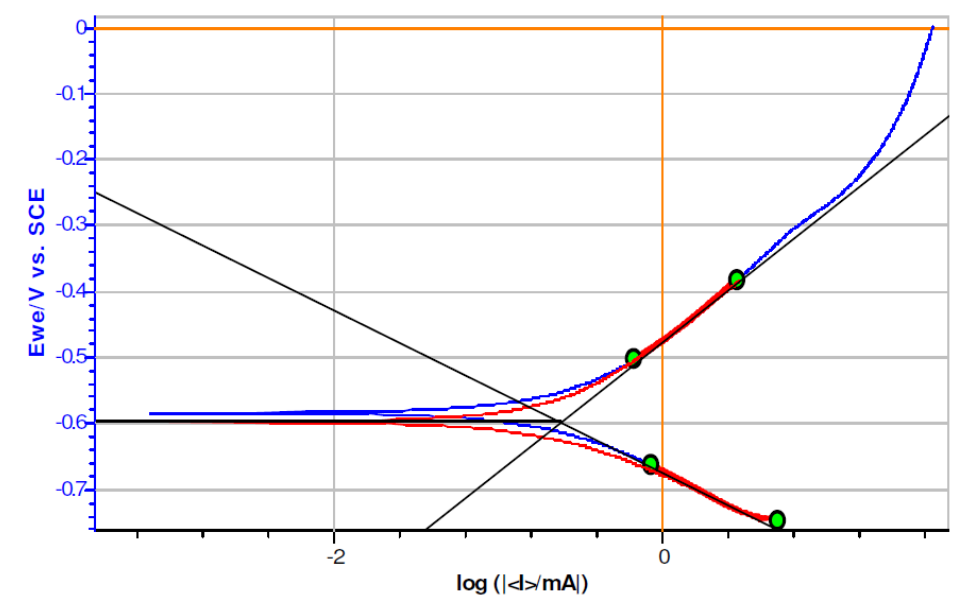

Figure 12. Potentiometric polarization curve for $1 \mathrm{~N} \mathrm{HCl}$ medium, in the presence of 900 ppm concentration of Commelina benghalensis leaves extract.

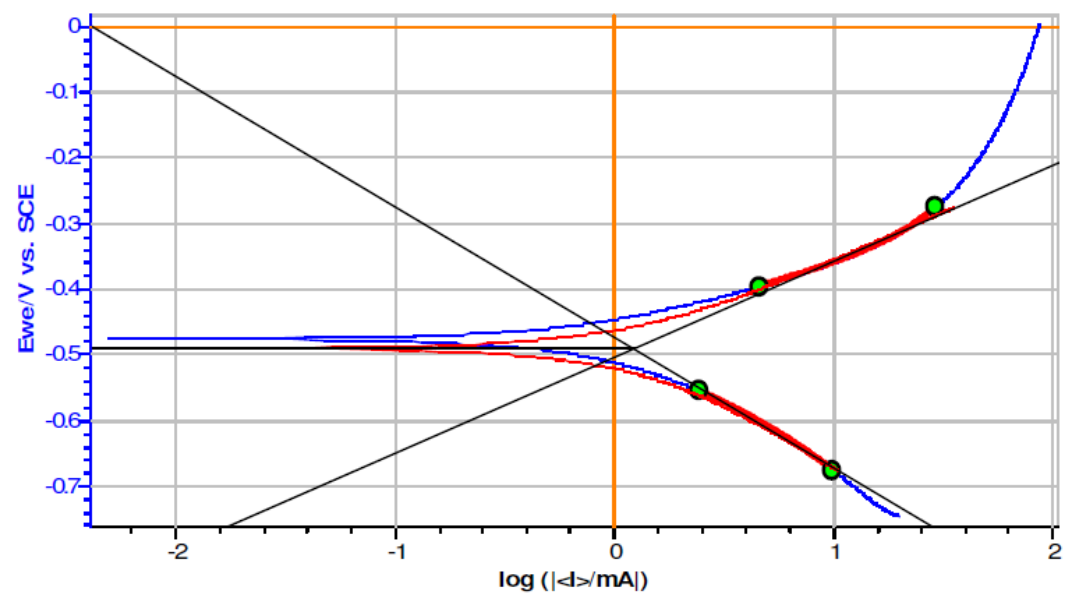

Figure 13. Potentiometric polarization curve for mild steel in $0.5 \mathrm{M} \mathrm{H}_{2} \mathrm{SO}_{4}$.

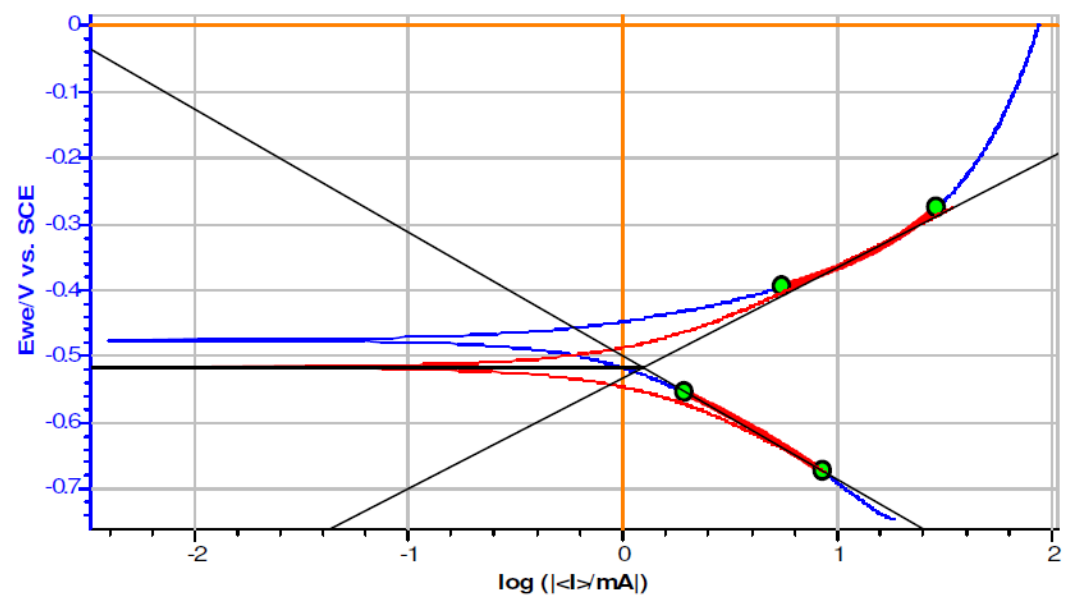

Figure 14. Potentiometric polarization curve for $0.5 \mathrm{M} \mathrm{H}_{2} \mathrm{SO}_{4}$ medium, in the presence of 100 ppm concentration of Commelina benghalensis leaves extract. 


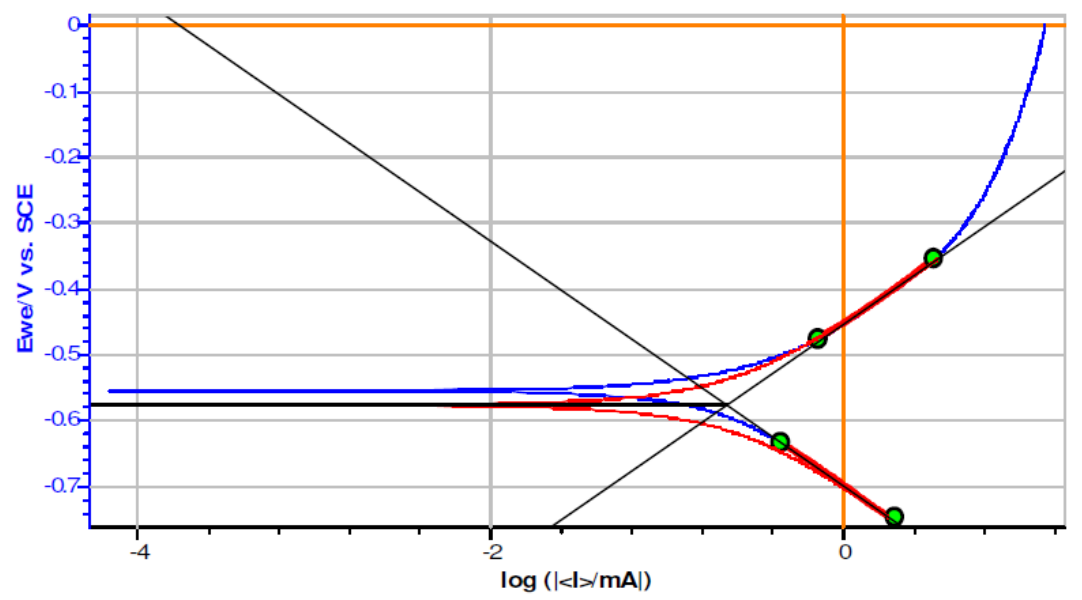

Figure 15. Potentiometric polarization curve for $0.5 \mathrm{M} \mathrm{H}_{2} \mathrm{SO}_{4}$ medium, in the presence of 900 ppm concentration of Commelina benghalensis leaves extract.

\section{AC impedance study}

AC impedance spectra have been used to investigate the formation of a protective film on the metal surface, during the corrosion inhibition process. When there is corrosion inhibition, charge transfer resistance value increases, and double layer capacitance decreases [43-48].

Tables 16 and 18 and Figs. 16 to 21 indicate AC impedance curves and values for the inhibitor concentration. The $\mathrm{R}_{\mathrm{t}}$ value increases, and $\mathrm{C}_{\mathrm{dl}}$ value decreases with the inhibitor concentration. This implies the formation of a protective film on the metal surface. It can be also seen from Tables 17 and 19 that there is a close agreement between the inhibition efficiencies values obtained from weight loss measurements, polarization and impedance studies. In the inhibitor presence, a protective film is formed on the metal surface. It prevents electrons transfer from the metal surface to the solution's bulk. That is why there is an increase in the resistance to the electron transfer, and, in the inhibitor presence, the charge transfer resistance increases.

Table 16. Corrosion parameters obtained from the impedance study for mild steel in $1 \mathrm{~N} \mathrm{HCl}$, in the presence and absence of Commelina benghalensis leaves extract.

\begin{tabular}{|c|c|c|c|}
\hline $\begin{array}{c}\text { [Inhibitor] } \\
\mathbf{p p m}\end{array}$ & $\begin{array}{c}\mathbf{R}_{\mathbf{t}} \\
\mathbf{O h m ~}^{\mathbf{2}} \mathbf{~ c m}^{\mathbf{2}}\end{array}$ & $\begin{array}{c}\mathbf{C}_{\mathbf{d l}}, \mathbf{\mathbf { F } ^ { 2 }} \\
\mathbf{F m}^{\mathbf{2}}\end{array}$ & $\begin{array}{c}\text { Inhibition } \\
\text { efficiency (\%) }\end{array}$ \\
\hline Blank & 16.3 & 0.150 & ----- \\
\hline 100 & 17.1 & 0.123 & 18.00 \\
\hline 900 & 39.0 & 0.008 & 94.61 \\
\hline
\end{tabular}

Table 17. Comparison of the inhibition efficiency measured by weight loss, polarization and impedance studies for $1 \mathrm{~N} \mathrm{HCl}$.

\begin{tabular}{|c|c|c|c|}
\hline \multirow{2}{*}{$\begin{array}{c}\text { [Inhibitor] } \\
\text { ppm }\end{array}$} & \multicolumn{3}{|c|}{ Inhibition efficiency (\%) } \\
\cline { 2 - 4 } & Weight loss study & Polarization study & Impedance study \\
\hline 100 & 17.27 & 17.98 & 18.00 \\
\hline 900 & 93.40 & 94.69 & 94.61 \\
\hline
\end{tabular}


Table 18. Corrosion parameters obtained from the impedance study for mild steel in $0.5 \mathrm{M} \mathrm{H}_{2} \mathrm{SO}_{4}$, in the presence and absence of Commelina benghalensis leaves extract.

\begin{tabular}{|c|c|c|c|}
\hline $\begin{array}{c}\text { [Inhibitor] } \\
\text { ppm }\end{array}$ & $\begin{array}{c}\mathbf{R}_{\mathrm{t}} \\
\text { Ohm } \mathbf{c m}^{2}\end{array}$ & $\begin{array}{c}\mathrm{C}_{\mathrm{dl}}, \\
\mathrm{F} / \mathrm{cm}^{2}\end{array}$ & $\begin{array}{c}\text { Inhibition } \\
\text { efficiency }(\%)\end{array}$ \\
\hline Blank & 10.7 & 0.137 & ----- \\
\hline 100 & 11.1 & 0.126 & 8.02 \\
\hline 900 & 110.0 & 0.018 & 86.86 \\
\hline
\end{tabular}

Table 19. Comparison of the inhibition efficiency measured by weight loss, polarization and impedance studies for $0.5 \mathrm{M} \mathrm{H}_{2} \mathrm{SO}_{4}$.

\begin{tabular}{|c|c|c|c|}
\hline \multirow{2}{*}{$\begin{array}{c}\text { [Inhibitor] } \\
\text { ppm }\end{array}$} & \multicolumn{3}{|c|}{ Inhibition efficiency (\%) } \\
\cline { 2 - 4 } & Weight loss study & Polarization study & Impedance study \\
\hline 100 & 8.92 & 8.15 & 8.02 \\
\hline 900 & 85.71 & 86.60 & 86.86 \\
\hline
\end{tabular}

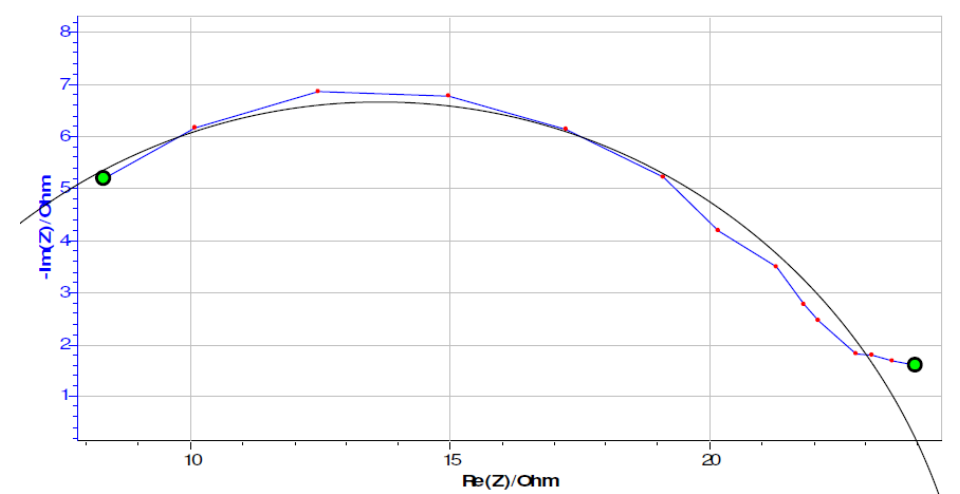

Figure 16. Impedance diagram for mild steel in $1 \mathrm{~N} \mathrm{HCl}$.

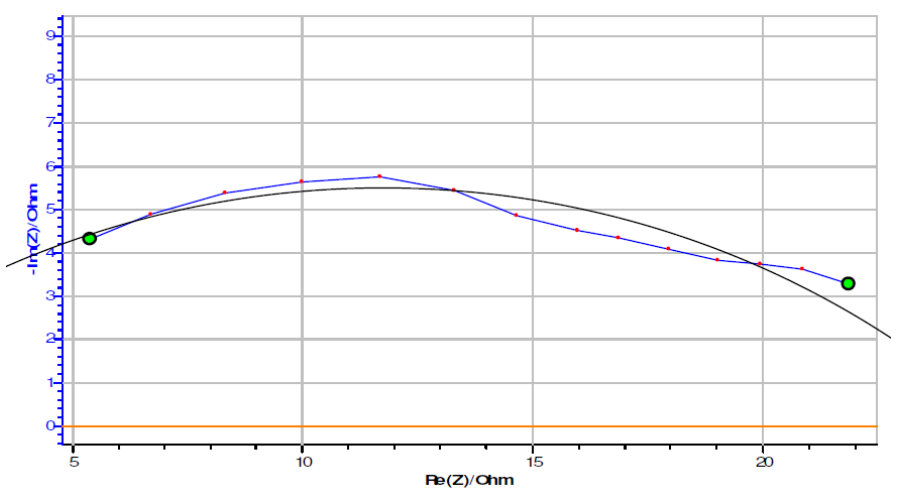

Figure 17. Impedance diagram for mild steel in $1 \mathrm{~N} \mathrm{HCl}$ medium, in the presence of 100 ppm concentration of Commelina benghalensis leaves extract. 


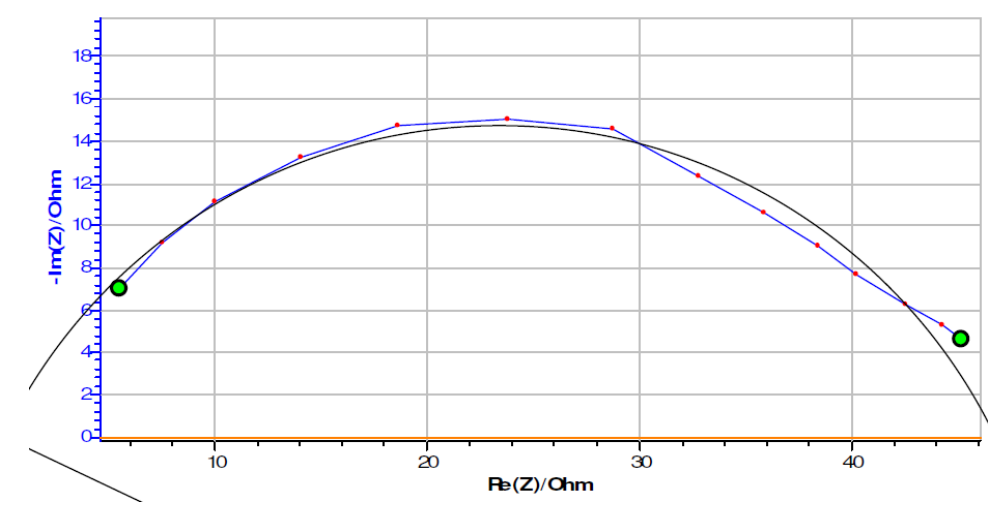

Figure 18. Impedance diagram for mild steel in $1 \mathrm{~N} \mathrm{HCl}$ medium, in the presence of 900 ppm concentration of Commelina benghalensis leaves extract.

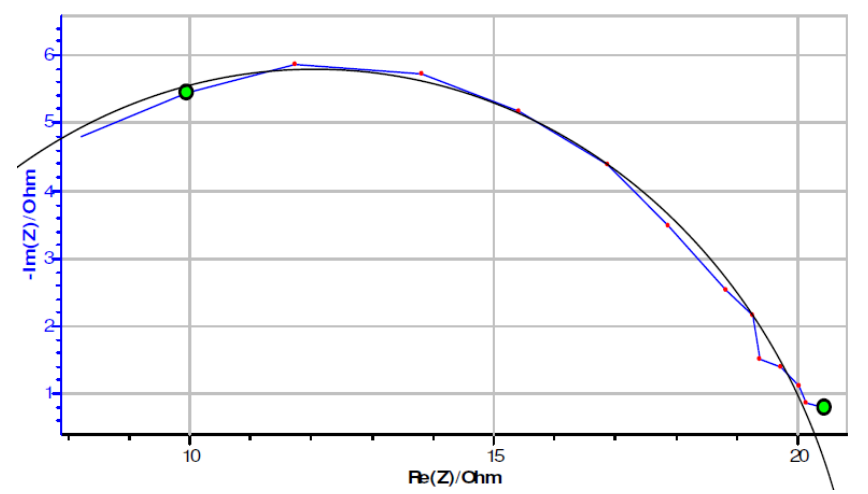

Figure 19. Impedance diagram for mild steel in $0.5 \mathrm{M} \mathrm{H}_{2} \mathrm{SO}_{4}$.

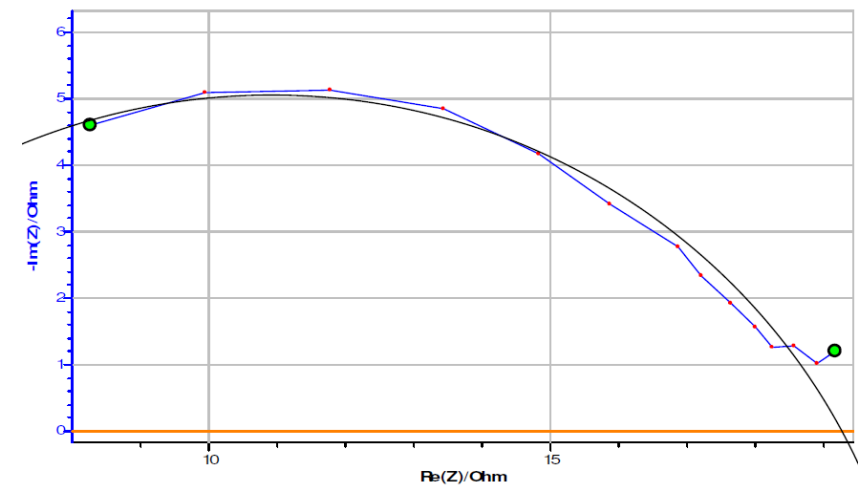

Figure 20. Impedance diagram for mild steel in $0.5 \mathrm{M} \mathrm{H}_{2} \mathrm{SO}_{4}$ medium, in the presence of 100 ppm concentration of Commelina benghalensis leaves extract.

It is inferred from the Nyquist plots that the process represents simple corrosion and corrosion resistance. The equivalent circuit diagram for such a system is shown in Fig. 22. 


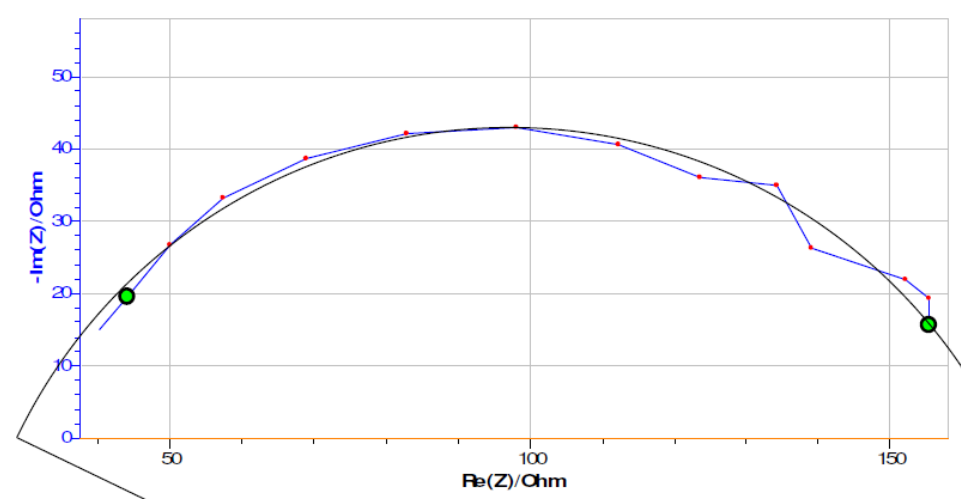

Figure 21. Impedance diagram for mild steel in $0.5 \mathrm{M} \mathrm{H}_{2} \mathrm{SO}_{4}$ medium, in the presence of 900 ppm concentration of Commelina benghalensis leaves extract.

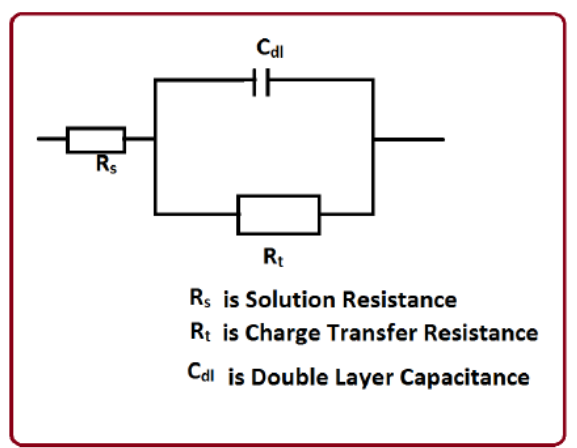

Figure 22. Equivalent circuit diagram for a simple corrosion and corrosion inhibition process.

\section{Conclusion}

The inhibitive influence of Commelina benghalensis leaves extract on mild steel corrosion in $1 \mathrm{~N} \mathrm{HCl}$ and $0.5 \mathrm{M} \mathrm{H}_{2} \mathrm{SO}_{4}$ was studied by the weight loss method, polarization and impedance measurements. The inhibition efficiency values determined by these techniques showed close agreement. The corrosion decreased with the increasing addition of Commelina benghalensis leaves extract, probably due to the progressive adsorption of the inhibitor onto the metal surface. The maximum inhibition efficiency was found to be $93.40 \%$ in $1 \mathrm{~N} \mathrm{HCl}$, and $85.71 \%$ in $0.5 \mathrm{M} \mathrm{H}_{2} \mathrm{SO}_{4}$.

1. Mild steel corrosion in $1 \mathrm{~N} \mathrm{HCl}$ and $0.5 \mathrm{M} \mathrm{H}_{2} \mathrm{SO}_{4}$ solutions was inhibited by the addition of Commelina benghalensis leaves extract.

2. The percentage of inhibition efficiency increased with higher inhibitor concentrations.

3. The corrosion inhibition of Commelina benghalensis leaves extract is attributed to the adsorption of any of the phyto-chemical components present in the inhibitor onto the mild steel surface. The adsorption was assumed to arise from the $\pi$-bond of the components onto the mild steel surface.

4. The values obtained from the weight loss technique for the studied inhibitor fit into the Langmuir and Temkin adsorption isotherms and the kinetic thermodynamic model. The free energy values for the adsorption 
processes indicate both physisorption and chemisorption (comprehensive adsorption) of the studied Commelina benghalensis leaves extract onto the mild steel surface.

5. AC impedance studies reveal that a protective film was formed on the metal surface.

6. The results suggest that Commelina benghalensis leaves extract is a great eco-friendly inhibitor.

7. The corrosion inhibition mechanism occurred by adsorption of the active principles of the extract ingredients onto the metal surface.

\section{Acknowledgement}

The authors are thankful to their managements for their help and encouragement.

\section{References}

1. Chraibi M, Benbrahim KF, Elmsellem H, et al. J Mater Environ Sci. 2017;8:972.

2. Ajeigbe SO, Basar N, Maarof H, et al. J Mater Environ Sci. 2017;8:2040.

3. Sivakumar PR, Srikanth AP. Asian J. Chem. 2017;29:274.

4. Kalla A, Benahmed M, Djeddi N, et al. Int . Ind Chem. 2016;7:419.

5. Singh A, Ahamad I, Quraishi MA. Arab J Chem. 2016;9:S1584.

6. Júnior JMF, Silva MGV, Monteiro JA, et al. Int J Electrochem Sci. 2016;11:3862.

7. $\quad$ Etteyeb N, Nóvoa XR. Corros Sci. 2016;112:471.

8. Ituen E, James A, Akaranta O, et al. Chin J Chem Eng. 2016;24:1442.

9. dos Santos JEP, Barroso APRN, Parente MMV, et al. Rev Materia. 2016;21:1045.

10. Umoren SA. J Adhes Sci Technol. 2016;30:1858.

11. Anthony N, Malarvizhi E, Maheshwari P, et al. Indian J Chem Technol. 2014;11:346.

12. Rajendran S, Amalraj AJ, Joice MJ, et al. Corros Rev. 2014;22:233.

13. Rajendran S, Ganga Sri V, Arockiaselvi J, et al. Bull Electrochem. 2005;21:367.

14. Rajendran S, Muthulakshmi S, Rajeswari R, et al. J Electrochem Soc. 2005;54:50.

15. Priya SL, Chitra A, Rajendran S, et al. Surf Eng. 2005;21:229.

16. Shanmugapriya S, Rajalakshmi T, Amal Raj AJ. Corrosion. 2005;61:685.

17. Anuradha K, Vimala R, Narayanasamy B, et al. Chem Eng Comm. 2008; 195:352.

18. Selvi JA, Gangasree V, Rajendran S. Port Electrochim Acta. 2008;27:1.

19. Rajendran S, Jeyasundari J, Selvi JA, et al. Port Electrochim Acta. 2009;27:153.

20. Rajendran S, Paulraj J, Rengan P, et al. J Dent Oral Hyg. 2009;1:1.

21. Rajendran S, Manivannan M. Zastit Mater. 2009;50:131.

22. Rajendran S, Agasta M, Devi RB, et al. Zastit Mater. 2009;50:77.

23. Rajendran S, Sumithira P, Devi BS, et al. Zastit Mater. 2009;50:223. 
24. Rajendran S, Uma V, Krishnaveni A, et al. Arab J Sci Eng. 2009;34:47.

25. Anthony N, Sherina HB, Rajendran S. Int J Eng Sci Tech. 2009;2:2774.

26. Rajendran S, Sumithra P, Devi BS, et al. Zastit Mater. 2009;5:223.

27. Sangeetha M, Rajendran S, Megala TSM, et al. Zastit Mater. 2009;52:35.

28. Devi BS, Rajendran S. Int J Electrochem Sci Tech. 2009;1:79.

29. Sirbharathy V, Rajendran S, Sathyabama J. Int J Chem Sci Tech. 2011;1:108.

30. Sangeetha M, Rajendran S, Bama JS, et al. Port Electrochim Acta. 2011;29:429.

31. Sangeetha M, Sathyabama J, Rajendran S, et al. Nat Prod Plant Res. 2012;2:601.

32. Florence JF, Rajendran S, Srinivasan KV. Electroplating Finishing. 2012;31:1.

33. Sirbharathy V, Rajendran S. Chem Sci Rev Lett. 2012;1:25.

34. Rajam K, Rajendran S, Banu NN. J Chem. 2012;11: 521951.

35. Johnsirani V, Sathiyabama J, Rajendran S, et al. ISRN Corros. 2012;9:574321.

36. Sribharathy V, and Rajendran S. ISRN Corros, Article ID 370802, 2012, 7.

37. Tadesse S, Ganesan K, Nair SKP, et al. Int J Pharm, Chem Biol Sci. 2016;6:103.

38. Shanmugapriya S, Rajendran S, Prabakar P, et al. Int J Nano Corr Sci Eng. 2016;3:144.

39. Anusuya S, Meenakshi SD. Int J Nano Corr Sci Eng. 2016;3:204.

40. Abinaya M, Meenakshi SD. Int J Nano Corr Sci Eng. 2016;3:216.

41. Rajendran S, Krishnaveni A, Muthukumar G. Int J Nano Corr Sci Eng. 2016;3:254.

42. Thangakani JA, Rajendran S, Sathiabama J. Int J Nano Corr Sci Eng. 2016;3:280.

43. Lavanyaa M, Suganya M. Int J Nano Corr Sci Eng. 2016;3:88.

44. Vanitha AJ, Raja AS, Rajendran S. Int J Nano Corr Sci Eng. 2016;3:223.

45. Anandan A, Rajendran S, Sathiyabama J, et al. Int J Nano Corr Sci Eng. 2016;3:9.

46. Nithya K, Meenakshi SD. Int J Nano Corr Sci Eng. 2016;3:44.

47. Devi PN, Sathiyabama J, Rajendran S, et al. Int J Nano Corr Sci Eng. 2016;3:56.

48. Madhumitha S, Priyadharshini V, Sheela A, et al. Int J Nano Corr Sci Eng. 2016;3:80. 